\title{
Session 1: Opening plenary session
}

Wednesday 6 October 2004. Moderator: Mark C. Glassy

[09.00-09.45]

[Plenary Lecture]

Update on chimeric and humanized monoclonal

antibodies in cancer therapy

Robert O. Dillman

Hoag Cancer Center, Newport Beach, CA, USA

Abstract not received. 